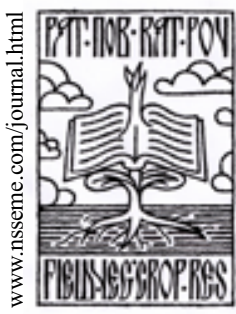

\title{
Evaluation of Rapid Protocols for DNA Isolation from Cercospora beticola Sacc.
}

\author{
Dragana Budakov • Nevena Nagl • Ksenija Taški-Ajduković • \\ Vera Stojšin • Ferenc Bagi
}

received: 15 November 2011, accepted: 6 April 2012

(C) 2012 IFVC

doi: $10.5937 /$ ratpov $49-1198$

\begin{abstract}
Summary: The most fungal DNA isolation protocols are designed to obtain high amounts of very pure DNA, requiring large fungal cultures and extraction procedures with many purification steps. Since the PCR does not require high purity DNA, the aim of this investigation was to evaluate three fast and simple fungal DNA isolation protocols for further use in Cercospora PCR based research. The purity and quantity of isolated DNAs were determined spectrophotometrically, electrophoretically and by PCR reaction with universal primers. The amounts of DNA evaluated on agarose gels, isolated by protocols A and C, did not correspond to the spectrophotometrical values, probably due to RNA impurities. In samples isolated by protocol B these impurities were not detected and the DNA concentrations were more similar. Neither protocol eliminated impurities such as carbohydrates and phenol. The average DNA yield of protocol A was $1.04 \mu \mathrm{g} / \mu \mathrm{l}$, protocol B $0.88 \mu \mathrm{g} / \mu \mathrm{l}$, and protocol C $0.55 \mu \mathrm{g} / \mu \mathrm{l}$. The DNA quality most suitable for PCR analysis was obtained by protocol $\mathrm{A}$, where amplification product with universal primers was detected in all DNA samples. The amplification product was detected in $87 \%$ of samples isolated by protocol C and in only $60 \%$ of samples isolated by protocol B. Although DNA obtained by protocol A had the highest yield and best quality, the isolation protocol $\mathrm{C}$ should be also recommended, for it does not require phenol, chlorophorm or liquid nitrogen.
\end{abstract}

Key words: Cercospora, DNA, impurity, isolation, protocol

\section{Introduction}

Cercospora leaf spot of sugar beet (Beta vulgaris L.) caused by Cercospora beticola Sacc. is the most important foliar disease of sugar beet in warm and humid agroecological conditions. In the absence of control measures in areas with high disease incidence, severe epidemics of Cercospora can result in significant reduction in root yield, recoverable sugar, percent of sucrose and increased concentration of impurities resulting in higher processing costs (Jacobsen \& Franc 2009, Shane \& Teng 1992, Windels et al. 1998).

Considering the economical impact of Cercosporaonsugarbeet production, it isimportant to develop methods for successful DNA analysis, in order to further improve understanding of this

\footnotetext{
N. Nagl* • K. Taški-Ajduković

Institute of Field and Vegetable Crops, Maksima Gorkog 30, 21000 Novi Sad, Serbia

e-mail: nevena.nagl@ifvcns.ns.ac.rs

D. Budakov • V. Stojšin • F. Bagi

University of Novi Sad, Faculty of Agriculture, Trg Dositeja Obradovića 8,21000 Novi Sad, Serbia
}

important pathogen. The first step in development of DNA-based techniques is establishment of suitable DNA isolation protocols. The most fungal DNA isolation protocols require relatively large fungal cultures and long extraction procedures for obtaining high amounts of very pure DNA. These protocols are not necessary for experiments with polymerase chain reaction (PCR), since it does not require use of high purity DNA. Having in mind that PCR can amplify small amounts of low purity DNA, the aim of our research was to evaluate three fast and simple fungal DNA isolation protocols and determine which could be the most suitable for use in further investigation of Cercospora genome.

\section{Materials and Methods}

Sugar beet leaves with typical symptoms of Cercospora leaf spot were collected from sugar beet fields in Vojvodina, Serbia. After monosporial isolations from collected leaves, the obtained isolates were transferred on potato dextrose agar

Supported by Ministry of Education and Science of the Republic of Serbia, Project No. TR31015 


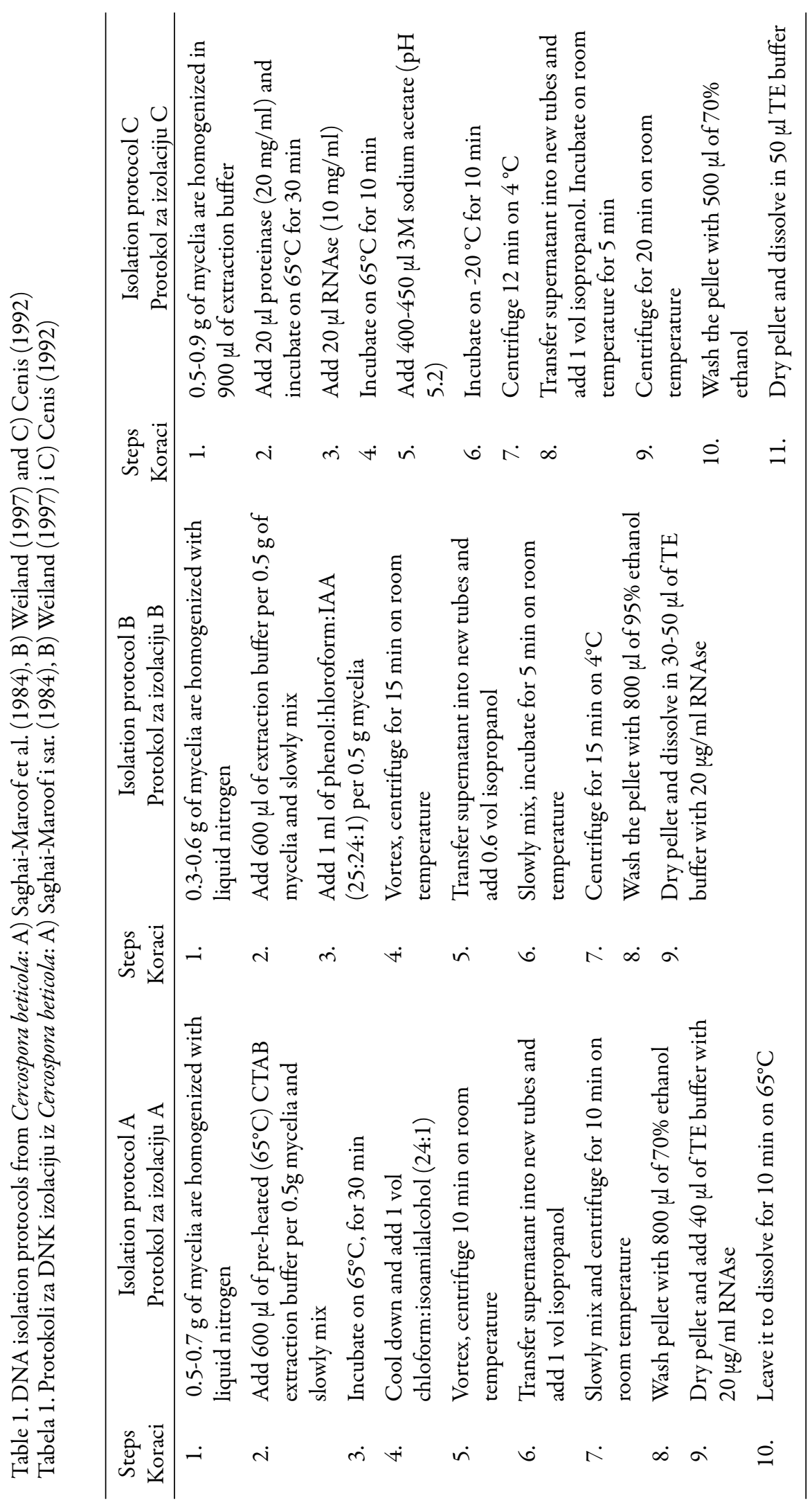


Table 2. Extraction buffers for DNA isolation from Cercospora beticola: A) Saghai-Maroof et al. (1984), B) Weiland (1997) and C) Cenis (1992)

Tabela 2. Puferi za izolaciju DNK iz Cercospora beticola: A) Saghai-Maroof i sar. (1984), B) Weiland (1997) i C) Cenis (1992)

\begin{tabular}{lll}
\hline Extraction buffer A & $\begin{array}{l}\text { Extraction buffer B } \\
\text { Pufer za ekstrakciju A }\end{array}$ & $\begin{array}{l}\text { Extraction buffer C } \\
\text { Pufer za ekstrakciju C }\end{array}$ \\
\hline $0.1 \mathrm{M}$ TRIS $(\mathrm{pH} 7.5)$ & $0.1 \mathrm{M}$ TRIS $(\mathrm{pH} 8)$ & $0.2 \mathrm{M} \mathrm{TRIS}(\mathrm{pH} 8.5)$ \\
$10 \mathrm{mM} \mathrm{EDTA}$ & $20 \mathrm{mM} \mathrm{EDTA}$ & $25 \mathrm{mM}$ EDTA \\
$0.7 \mathrm{M} \mathrm{NaCl}$ & $0.5 \mathrm{M} \mathrm{NaCl}$ & $0.25 \mathrm{M} \mathrm{NaCl}$ \\
$1 \% \mathrm{CTAB}(10 \%)$ & $1 \% \mathrm{SDS}(10 \%)$ & $1 \% \mathrm{SDS}(10 \%)$ \\
$0.1 \mathrm{mg} / \mathrm{ml}$ Proteinase $\mathrm{K}(20 \mathrm{mg} / \mathrm{ml})^{*}$ & $0.075 \mathrm{mg} / \mathrm{ml}$ Proteinase $\mathrm{K}(20 \mathrm{mg} / \mathrm{ml})^{*}$ & \\
$1 \% 2-$ mercaptoethanol & & \\
\hline
\end{tabular}

* Added prior to use

(PDA) slants and kept refrigerated at $4{ }^{\circ} \mathrm{C}$ until further analysis. Fifteen randomly chosen isolates were grown on PDA in $90 \mathrm{~mm}$ diameter Petri dishes, on $25-26^{\circ} \mathrm{C}$, for 7 to 10 days, with 3 mycelial plugs per isolate ( $5 \mathrm{~mm}$ in diameter) turned upside down. Three methods for fungal DNA isolation were evaluated: A) Saghai-Maroof et al. (1984), B) Weiland (1997) and C) Cenis (1992), with some modifications (Tab. 1).

In the first two protocols, mycelia were scraped from solid medium, measured and homogenized with liquid nitrogen. The first modification was performed in step 2, when $600 \mu \mathrm{l}$ of extraction buffer (Tab. 2) was added per $0.5 \mathrm{~g}$ of mycelia. The protocols were further followed without modifications. The extracted DNAs were diluted in 30-50 $\mu \mathrm{l}$ of TE buffer. In protocol according to Cenis (1992) mycelia homogenization was done on room temperature in extraction buffer (Tab. 2). In order to further improve DNA purification, in additional steps (2-5) proteinase and RNAse were added.

Concentration of obtained DNA was measured by visualization on $1 \%$ agarose gels in $0.5 \times \mathrm{TBE}$ buffer with ethidium bromide $(0.5 \mathrm{~g} / \mathrm{ml})$ added to the gel. The $\lambda$ phage DNA concentration of $25 \mathrm{ng}$, $50 \mathrm{ng}, 100 \mathrm{ng}$ and $250 \mathrm{ng}$ were used as standards. Images were taken under UV light.

The purity and quantity of isolated DNA were determined spectrophotometrically (Ultraspec 2000 Pharmacia Biotech). Optical density (OD) values at 230, 260 and $280 \mathrm{~nm}$ were recorded. The quality of the isolated DNA was also evaluated by PCR reaction with universal primers $U_{1}$ (TCTGCCCTATCAACTTTCGATGCTA) and $\mathrm{U}_{2}$ (AATTTGCGCGCCTGCTGCCTTCCTT) specific for $18 \mathrm{~S}$ rRNA, part of the small ribosomal subunit, following the amplification program: denaturation at $95^{\circ} \mathrm{C}$ for $2 \mathrm{~min}$ followed by 35 cycles of $95^{\circ} \mathrm{C}$ for $25 \mathrm{~s}, 60^{\circ} \mathrm{C}$ for $30 \mathrm{~s}$ and $68^{\circ} \mathrm{C}$ for 45 s, with final extension at $68^{\circ} \mathrm{C}$ for $10 \mathrm{~min}$. PCR products were separated on $1 \%$ agarose gels. $100 \mathrm{bp}$ ladder (Fermentas) was used as size reference.

\section{Results and Discussion}

The yield and purity of isolated Cercospora beticola DNA differed among isolates and isolation protocols. When DNA concentration and purity was evaluated visually on agarose gels (Fig. 1a, $2 \mathrm{a}, 3 \mathrm{a})$ it could be noticed that amounts of DNA isolated by protocols $\mathrm{A}$ and $\mathrm{C}$ did not correspond to the yield detected spectrophotometrically (Tab. 3 ). This is not unexpected since RNA impurities could be seen on the gels with DNA isolated by those two protocols, and it is known that impurities in DNA solution caused by RNA can not be confidently identified by spectrophotometry (Somma 2004). In samples isolated by protocol $\mathrm{B}$ these impurities could not be detected on agarose gel (Fig. 2a) and the DNA concentrations were more similar to the corresponding values, determined spectrophotometrically (Tab. 3).

The ratio of ODs at $260 \mathrm{~nm}$ and $280 \mathrm{~nm}$ is commonly used to assess the purity of DNA with respect to protein contamination, since proteins (in particular, the aromatic amino acids) tend to absorb at $280 \mathrm{~nm}$ (Sambrook \& Russell 2001). A ratio of approximately 1.8 is generally accepted as pure DNA. If the ratio is lower, it may indicate the presence of protein or other contaminants that absorb at or near $280 \mathrm{~nm}$. We observed that the average ratio of OD values at $260 / 280 \mathrm{~nm}$ for tested protocols were similar (1.6 - 1.7) (Tab. 3). The OD values varied from 1.4 to 1.8 in samples isolated by protocol A, from 1.5 to 1.9 in samples isolated by protocol B and from 1.3 to 1.9 in samples isolated using protocol C. The obtained 

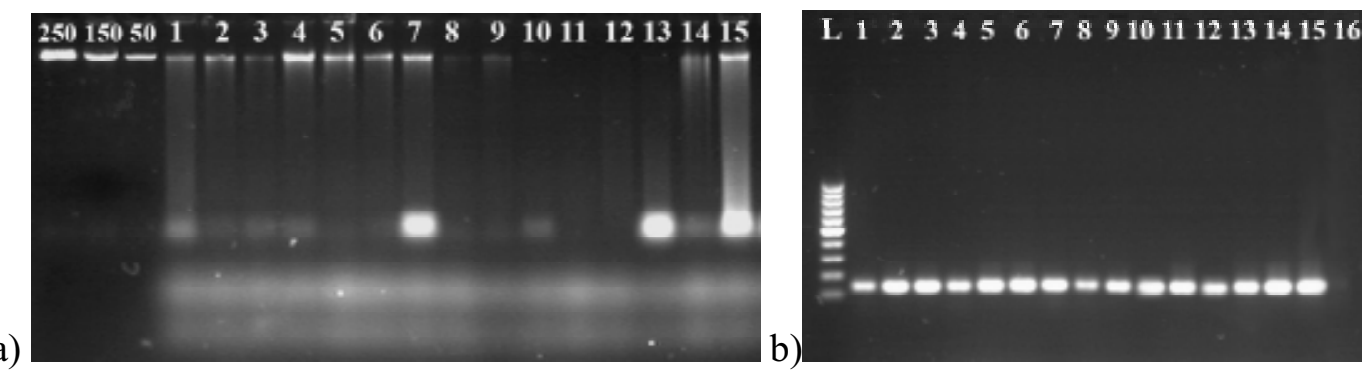

Figure 1. DNA isolation from Cercospora beticola according to protocol A: a) Isolated DNAs, b) Products of amplification with universal primers $(250$ - $250 \mathrm{ng} \lambda \mathrm{DNA}, 100-100 \mathrm{ng} \lambda \mathrm{DNA}, 50$ - $50 \mathrm{ng} \lambda \mathrm{DNA}, \mathrm{L}$ 100 bp ladder, 1-15 - Cercospora isolates, 16 - water)

Slika 1. Izolacija DNK iz Cercospora beticola prema protokolu A: a) Izolovana DNK, b) Produkti amplifikacije sa univerzalnim prajmerima $(250$ - $250 \mathrm{ng} \lambda \mathrm{DNA}, 100-100 \mathrm{ng} \lambda \mathrm{DNA}, 50$ - $50 \mathrm{ng} \lambda \mathrm{DNA}$, L - 100 bp lestvica, 1-15 - Cercospora izolati, 16 - voda)

a)

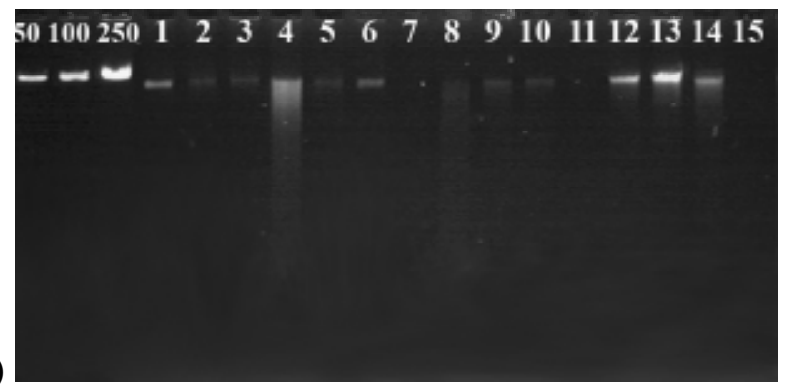

b)

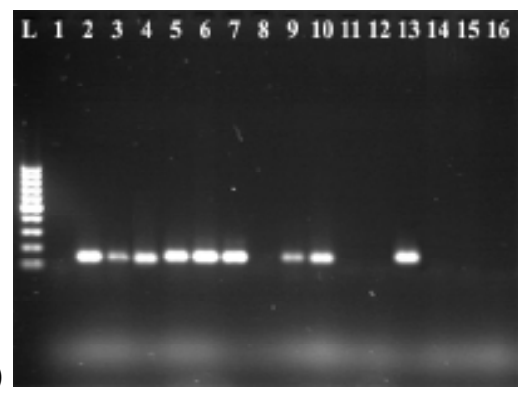

Figure 2. DNA isolation from Cercospora beticola according to protocol B: a) Isolated DNAs, b) Products of amplification with universal primers $(50$ - $50 \mathrm{ng} \lambda \mathrm{DNA}, 100-100 \mathrm{ng} \lambda \mathrm{DNA}, 250$ - $250 \mathrm{ng} \lambda \mathrm{DNA}, \mathrm{L}$ 100 bp ladder, 1-15 - Cercospora isolates, 16 - water)

Slika 2. Izolacija DNK iz Cercospora beticola prema protokolu B: a) Izolovana DNK, b) Produkti amplifikacije sa univerzalnim prajmerima (50 - $50 \mathrm{ng} \lambda$ DNA, 100 - $100 \mathrm{ng} \lambda$ DNA, 250 - $250 \mathrm{ng} \lambda$ DNA, L - 100 bp lestvica, 1-15 - Cercospora izolati, 16 - voda)
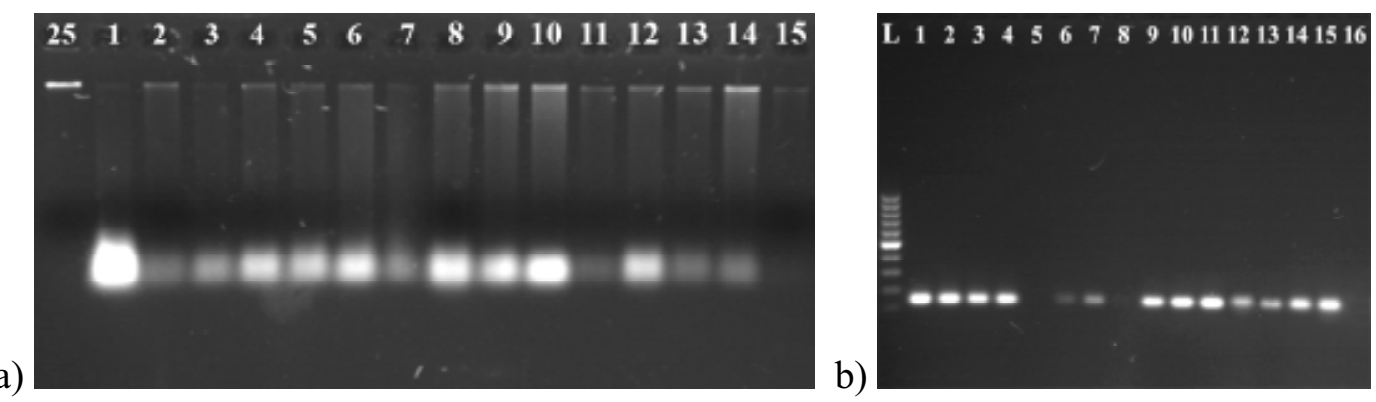

Figure 3. DNA isolation from Cercospora beticola according to protocol C: a) Isolated DNAs, b) Products of amplification with universal primers (25 - $25 \mathrm{ng} \lambda \mathrm{DNA}, \mathrm{L}-100 \mathrm{bp}$ ladder, 1-15 - Cercospora isolates, 16 - water)

Slika 3. Izolacija DNK iz Cercospora beticola prema protokolu C: a) Izolovana DNK, b) Produkti amplifikacije sa univrezalnim prajmerima (25 - $25 \mathrm{ng} \lambda$ DNA, L - 100 bp lestvica, 1-15 - Cercospora izolati, 16 - voda) 
Table 3. Concentration and purity of DNA samples isolated from Cercospora beticola according protocols: A) Saghai-Maroof et al. (1984), B) Weiland (1997) and C) Cenis (1992)

Tabela 3. Koncentracija i čistoća DNK uzoraka izolovanih prema protokolima za DNK izolaciju iz Cercospora beticola: A) Saghai-Maroof i sar. (1984), B) Weiland (1997) i C) Cenis (1992)

\begin{tabular}{|c|c|c|c|c|c|c|c|c|c|}
\hline \multirow{2}{*}{$\begin{array}{c}\text { Sample } \\
\text { No. } \\
\text { Broj uzorka }\end{array}$} & \multicolumn{3}{|c|}{$\begin{array}{c}\text { Isolation protocol A } \\
\text { Protokol za izolaciju A }\end{array}$} & \multicolumn{3}{|c|}{$\begin{array}{l}\text { Isolation protocol B } \\
\text { Protokol za izolaciju B }\end{array}$} & \multicolumn{3}{|c|}{$\begin{array}{l}\text { Isolation protocol C } \\
\text { Protokol za izolaciju C }\end{array}$} \\
\hline & $\begin{array}{l}\text { conc. } \\
(\mu \mathrm{g} / \mu \mathrm{l})\end{array}$ & $260 / 280$ & $260 / 230$ & $\begin{array}{l}\text { conc. } \\
(\mu \mathrm{g} / \mu \mathrm{l})\end{array}$ & $260 / 280$ & $260 / 230$ & $\begin{array}{l}\text { conc. } \\
(\mu \mathrm{g} / \mu \mathrm{l})\end{array}$ & $260 / 280$ & $260 / 230$ \\
\hline 1 & 1.70 & 1.6 & 1.1 & 1.42 & 1.6 & 1.3 & 0.88 & 1.8 & 1.3 \\
\hline 2 & 0.77 & 1.7 & 1.3 & 0.30 & 1.5 & 0.1 & 0.29 & 1.7 & 1.1 \\
\hline 3 & 0.71 & 1.6 & 1.1 & 0.57 & 1.7 & 0.2 & 0.44 & 1.9 & 1.5 \\
\hline 4 & 0.78 & 1.7 & 1.2 & 0.55 & 1.5 & 1.1 & 0.56 & 1.8 & 1.3 \\
\hline 5 & 0.87 & 1.5 & 1.0 & 0.78 & 1.5 & 1.3 & 0.53 & 1.9 & 1.5 \\
\hline 6 & 0.88 & 1.7 & 1.3 & 1.53 & 1.8 & 1.6 & 0.86 & 1.8 & 1.6 \\
\hline 7 & 1.18 & 1.8 & 1.2 & 0.96 & 1.8 & 1.5 & 0.94 & 1.7 & 1.2 \\
\hline 8 & 0.81 & 1.4 & 1.0 & 0.47 & 1.6 & 1.3 & 1.29 & 1.8 & 1.5 \\
\hline 9 & 0.65 & 1.5 & 0.6 & 0.34 & 1.3 & 0.9 & 0.71 & 1.8 & 1.5 \\
\hline 10 & 0.25 & 1.4 & 0.9 & 0.38 & 1.6 & 1.3 & 0.18 & 1.6 & 0.9 \\
\hline 11 & 1.78 & 1.6 & 1.1 & 0.26 & 1.5 & 1.1 & 0.17 & 1.7 & 1.0 \\
\hline 12 & 1.05 & 1.6 & 1.1 & 1.62 & 1.8 & 1.4 & 0.90 & 1.5 & 0.9 \\
\hline 13 & 1.81 & 1.6 & 1.2 & 2.58 & 1.5 & 1.2 & 0.21 & 1.4 & 0.8 \\
\hline 14 & 2.09 & 1.7 & 1.2 & 1.21 & 1.7 & 1.4 & 0.18 & 1.3 & 0.8 \\
\hline 15 & 0.27 & 1.4 & 0.9 & 0.34 & 1.6 & 0.1 & 0.18 & 1.3 & 0.7 \\
\hline $\begin{array}{l}\text { Average } \\
\text { Prosek }\end{array}$ & 1.04 & 1.6 & 1.1 & 0.88 & 1.6 & 1.0 & 0.55 & 1.7 & 1.2 \\
\hline
\end{tabular}

values indicate that proteins in all protocols were sufficiently removed.

A secondary measure of nucleic acid purity was based on the ratio of OD values at $260 \mathrm{~nm}$ and $230 \mathrm{~nm}$ (Tab. 3). The 260/230 values for pure nucleic acid are often higher than the respective 260/280 OD values. Expected 260/230 values are commonly in the range of $2.0-2.2$. If the ratio is appreciably lower than expected, it may indicate the presence of contaminants which absorb at or near $230 \mathrm{~nm}$, such as carbohydrates and phenol. In tested samples of Cercospora DNA OD values were very low, which showed that neither protocol was successful in eliminating above mentioned impurities.

Such results are not surprising, since the isolation protocols used in this investigation are simple and do not include many purification steps. Nevertheless, having in mind that PCR is able to amplify DNA even in the presence of diverse impurities, the potential use of isolated DNAs in further molecular investigations on Cercospora was evaluated by using them as templates in PCR with universal primers (Fig. 1b, 2b, 3b). An expected amplification products size of 150 bp were detected in all samples where DNA was isolated using protocol A (Fig. 1b), in nine samples (60\%) where DNA was isolated using protocol B (Fig. 2b) and in thirteen samples (87\%) where DNA was isolated using protocol C (Fig. 3b). The results indicate that DNA isolated using protocol A (Saghai-Maroof et al. 1984) could be used for PCR analysis with all 15 samples. The main difference between this and other two protocols is the presence of mercaptoethanol in extraction buffer. Since mercaptoethanol is known to improve removal of polyphenols and tannins from crude fungal extract, this could be the reason for good performance of this protocol. The isolation protocol according to Cenis (1992) should be also recommended, for it does not require phenol or chlorophorm extraction, or use of liquid nitrogen, unlike other two protocols. Phenol and chlorophorm are toxic, hazardous, expensive, and require special containment, while the waste disposal requires special equipment and care to avoid human and environmental exposure (Niu et al.2008). Also, by using this protocol, the problems related to handling, storage and maintenance of liquid nitrogen could be avoided. 


\section{Conclusions}

Procedures in all tested protocols were sufficient for removal of protein contaminants. Neither protocol was successful in eliminating impurities which absorb at or near $230 \mathrm{~nm}$, such as carbohydrates and phenol. The most successful in isolating the Cercospora DNA suitable for PCR analysis was protocol A (Saghai-Maroof et al. 1984), where an amplification product was present in all samples. The isolation protocol according to Cenis (1992) has a high potential for future use, since in $87 \%$ of samples isolated DNA could be used in PCR. Also, it does not require phenol/ chlorophorm extraction or use of liquid nitrogen.

\section{References}

Cenis JL (1992): Rapid extraction of fungal DNA for PCR amplification. Nucl. Acids Res. 20: 2380

Jacobsen B, Franc G (2009): Cercospora leaf spot. In: RM Harveson, LE Hanson and GL Hein (eds.), Compendium of beet diseases and pests. APS Press, St. Paul, Minnesota, USA, 7-10

Niu C, Kebede H, Auld D, Woodward J, Burow G, Wright R (2008): A safe inexpensive method to isolate high quality plant and fungal DNA in an open laboratory environment. African J. Biotechnol. 7: 2818-2822

Saghai-Maroof MA, Soliman KM, Jorgensen RA, Allard RW (1984): Ribosomal DNA spacer-length polymorphism in barley: Mendelian inheritance, chromosomal location and population dynamics. Proc. Natl. Acad. Sci. USA 81: 8010-8018

Sambrook J, Russell DW (2001): Molecular Cloning: A Laboratory Manual. Cold Spring Harbor Laboratory Press, New York, USA

Shane WW, Teng PS (1992): Impact of Cercospora leaf spot on root weight, sugar yield and purity of Beta vulgaris. Plant Dis. 76: $812-820$

Somma M (2004): Extraction and purification of DNA. In: M Querci, M Jermini, G Van den Eade (eds.), The analysis of food samples for the presence of genetically modified organisms, special publication 1.03.114 ed. European Commision, Joint Research Centre: Ispra, Italy, Ch. 4

Weiland J (1997): Rapid procedure for extraction of DNA from fungal spores and mycelia. Fungal Genet. Newslet. 44: 60-63

Windels CE, Lamey HA, Hilde D, Widner J, Knudsen T (1998): Cercospora leaf spot model for sugar beet: in practice by the industry. Plant Dis. 82: 716-726

\title{
Procena protokola za brzu izolaciju DNK iz Cercospora beticola Sacc.
}

\author{
Dragana Budakov • Nevena Nagl • Ksenija Taški-Ajduković • \\ Vera Stojšin • Ferenc Bagi
}

Izvod: Sa ciljem uspostavljanja odgovarajućeg protokola izolacije DNK za primenu u istraživanjima zasnovanim na PCR analizi, u radu su ispitana tri jednostavna i brza metoda za DNK izolaciju iz Cercospora beticola Sacc. Čistoća i količina izolovane DNK je određena spektrofotometrijski, elektroforetski i PCR reakcijom sa univerzalnim prajmerima. Količina DNK procenjena na agaroznom gelu, koja je izolovana pomoću protokola $\mathrm{A}$ i C nije odgovarala spektrofotometrijskim vrednostima, verovatno usled prisustva RNK nečistoća. U uzorcima izolovanim pomoću protokola $B$ ove nečistoće nisu detektovane, pa su DNK koncentracije bile podudarne. Ni u jednom protokolu nisu eliminisane nečistoće, kao što su ugljeni hidrati i fenoli. PCR amplifikacija je uočena kod svih DNK uzoraka izolovanih protokolom A, kod 60\% uzoraka izolovanih protokolom B i kod $87 \%$ uzoraka izolovanih protokolom C. Iako je protokol za izolaciju A dao najbolje rezultate, protokol $\mathrm{C}$ se takođe može preporučiti, jer ne zahteva upotrebu fenola, hloroforma i tečnog azota. Ključne reči: Cercospora, DNK, izolacija, nečistoće, protokoli 